\title{
ALTERNATIVE WAYS OF FOAMED POLYSTYRENE RECYCLING USING INSECTS AS AN ELEMENT OF SUSTAINABLE DEVELOPMENT
}

\author{
Olga Kosewska ${ }^{1}$, inż; Agnieszka Kosewska ${ }^{1}$, dr hab.; Sebastian Przemieniecki ${ }^{1}$, dr inż. and \\ Stanislaw Sienkiewicz ${ }^{2}$, prof. dr hab. \\ ${ }^{1}$ Department of Entomology, Phytopathology and Molecular Diagnostics, University of Warmia and Mazury in \\ Olsztyn, Prawochenskiego 17, 10-720, Olsztyn, Poland; ${ }^{2}$ Department of Agricultural Chemistry and \\ Environmental Protection, University of Warmia and Mazury in Olsztyn, Oczapowskiego 8, 10-744, Olsztyn, \\ Poland
}

\begin{abstract}
Pursuant to the principles of sustainable development, so as not to diminish the chances of living on our planet for future generations, special attention should be paid to certain aspects of our economy, including waste management. This paper presents an alternative way of recycling Styrofoam, by employing larvae of one of the common warehouse pests, the mealworm beetle (Tenebrio molitor L.). The aims of the research were to assess the biometric and enzymatic parameters of T. molitor larvae fed on Styrofoam, and to evaluate their possible use to decompose polystyrene waste. The experiment consisted of maintaining larvae for 10 weeks on nutrient substrates composed of foamed polystyrene (the control substrate was composed of oatmeal flakes). During the experiment, the mass of insects and the mass of ingested substrate were controlled. On the termination of the culture, digestive tracts of larvae from each replication was dissected to determine the enzymatic activity of the digestive system cells. To the biochemical analyses were made using the API $®$ type assays. It has been demonstrated that owing to the enzymatic activity of the larval digestive tract and that of the gut microflora, mealworm larvae were able to digest waste slow to biodegrade, including polystyrene. A solution has been proposed, where providing suiTable conditions it will be possible to use mealworm larvae to utilise polystyrene waste.
\end{abstract}

Key words: biodegradation, Styrofoam, mealworm, sustainable development.

JEL code: 031

\section{Introduction}

The economic growth in many countries across the world, beside supporting the improved quality of life and stimulating enormous consumption, gives rise to an increasing problem of how to manage the waste generated by man. Waste has a direct impact on all compartments of the environment, i.e. air, water, and soil, often causing their degradation or devastation (Juda-Rezler, Manczarski, 2010). Plastic waste poses a particularly grave problem due to its long degradation period. The rather inefficient recycling of plastics nowadays means that huge amounts of this waste persist in the environment, polluting water or soil. The hydrosphere is penetrated by around $10 \%$ of all produced plastics (Thompson et al., 2009), of which a large share ends up in the marine environment (Jambeck et al., 2015). Polystyrene is one of the most widely made synthetic polymers. It has many uses, e.g. for insulation or packaging. Around 35 million tonnes of Styrofoam is produced annually, and this amount increases by an average of $5 \%$ each year (Baker, 2018).

According to the principles of sustainable development, which assumes that, irrespective of human activities, the Earth's resources should be preserved for future generations and our planet must not be damaged, new waste management technologies and plans ought to be designed. There are many ways in which waste can be managed, for example it can be stored, recovered and recycled, thermally neutralised via pyrolysis or incineration, etc. (Zebek, 2018). However, there are alternative approaches, less known yet highly innovative, e.g. a technology where living organisms are employed to decompose waste (Yang et al., 2014; Yang et al., 2015). For instance, some insects are capable of utilising synthetic material waste owing to the microorganisms they retain in their digestive tract that aid the digestion of such unusual food as plastics (Bombelli et al., 2017). Examples of such insects are mealworm beetle (Tenebrio molitor L.), caterpillar of honeycomb moth (Galleria 
mellonella L.), indianmeal moth (Plodia interpunctella Hübner) and morio worms (Zophobas morio Fabricius) (Ritter, 2017; Pelley, 2014).

Mealworm beetle (Tenebrio molitor) is a dark-brown beetle, with the body length of $15 \mathrm{~mm}$, which belongs to the darkling family (Tenebrionidae). It is a pest of cereals and cereal products, and in the natural environment it can be found in bird nests and under tree bark (Nawrot, 2001). This insect, owing to its high protein content, can be used as feed for animals (Ramos-Elorduy et al., 2002, Weiner et al., 2018) and as an alternative source of protein for humans (Siemianowska et al., 2013; Fialkowski 2016). Larvae of mealworm beetle, just like the adult form, mostly forage on cereal products, but are also capable of surviving on a diet composed of synthetic materials, e.g. Styrofoam, which they can decompose into biodegradable components (Drahl, 2015). The first step of this process consists of the fragmentation of Styrofoam by larvae chewing it, which increases the proper surface area of the material and improves the contact of this material with enzymes and microorganisms dwelling in the insect's digestive system. Once Styrofoam and intestinal microbiota mix, enzymes produced by the intestinal microorganisms and the ones produced by larvae are secreted. Thus, a reaction leading to the decomposition of foamed polystyrene under the influence of enzymes occurs, as a result of which small-molecular fragments are obtained. The energy generated from the decomposition of polystyrene foam is used by larvae for their living processes. During the reaction of Styrofoam decomposition, apart from the energy which powers larval living processes, carbon dioxide and undigested molecules are produced, with the latter being excreted by larvae as faeces (Yang et al., 2015).

The purpose of this research has been to assess the biometric and enzymatic parameters of mealworm larvae fed on Styrofoam, and to evaluate their possible use to decompose polystyrene waste with a long biodegradation time.

\section{Material and methods}

Larvae of the mealworm beetle originating from the culture maintained at the Department of Entomology, Phytopathology and Molecular Diagnostics of the University of Warmia and Mazury in Olsztyn, Poland, were used for the experiment. 100 larvae at the same developmental stage were selected and transferred to previously prepared substrates composed of comminuted Styrofoam (5 $\mathrm{g}$ in a $1 \mathrm{dm}^{3}$ container) and oatmeal flakes (20 g in a $1 \mathrm{dm}^{3}$ container) as the control substrate. In order to ensure an additional source of nitrogen, the tested substrates were enriched with about $1 \%$ (relative to the mass of the substrate) of dried distillers' grains with solubles (DDGS), a by-product of bioethanol production. The experiment was conducted in three replicates (4 variants $\times 3$ replications $x 100$ larvae). The mealworm larvae remained on the substrates for 10 weeks. Every 14 days, the mass of the substrates and the weight of larvae were measured. Following the biometric analysis of the larvae, the microbiota dwelling in their digestive system was analysed. Approximately $50 \mathrm{~g}$ of digestive tracts of larvae from each replication was prepared to determine the enzymatic activity of the digestive system cells, employing to this aim the biochemical assays types API 20 NE and API 20 E by Biomerieux, according to the manufacturer's instructions attached to the assays.

\section{Research results and discussion}

\section{Biometric analysis}

The biometric analysis of the mealworm beetle larvae lasting for 70 days revealed an increase in the average weight of larvae fed either type of a diet (Styrofoam or oatmeal) (Table 1). It was also observed that the average weight of larvae was higher when the substrate had been enriched with DDGS as a source of nitrogen. 


\section{Average weight [in $\mathrm{mg}$ ] 1 larva of Tenebrio molitor at the onset and termination of the experiment}

\begin{tabular}{|c|c|c|c|c|}
\hline \multirow{2}{*}{ Day of experiment } & \multicolumn{2}{|c|}{ Polystyrene } & \multicolumn{2}{c|}{ Oatmeal } \\
\cline { 2 - 5 } & Pure & (+) DDGS & Pure & $(+)$ DDGS \\
\hline $\mathbf{1}$ & 42.81 & 42.24 & 54.78 & 50.60 \\
\hline $\mathbf{7 0}$ & 64.15 & 66.84 & 61.72 & 63.08 \\
\hline
\end{tabular}

Source: author's calculations based on the experimental data

An analysis of the measurements taken revealed a specific trend. Irrespective of the applied diet, the mass of larvae decreased until around the 10th day of culture. Afterwards, there was a distinct increase in the mass until the 40th day of the experiment. Subsequently, the cycle repeated in 3 of the 4 tested variants (oatmeal with DDGS and oatmeal without DDGS as well as Styrofoam without added DDGS). The average weight of one insect decreased for about 15 days, after which it increased above the weight gained before the decrease phase. In the variant of Styrofoam with added DDGS, a second decrease in the average mass of the body of a larvae was not observed (Figure 1).

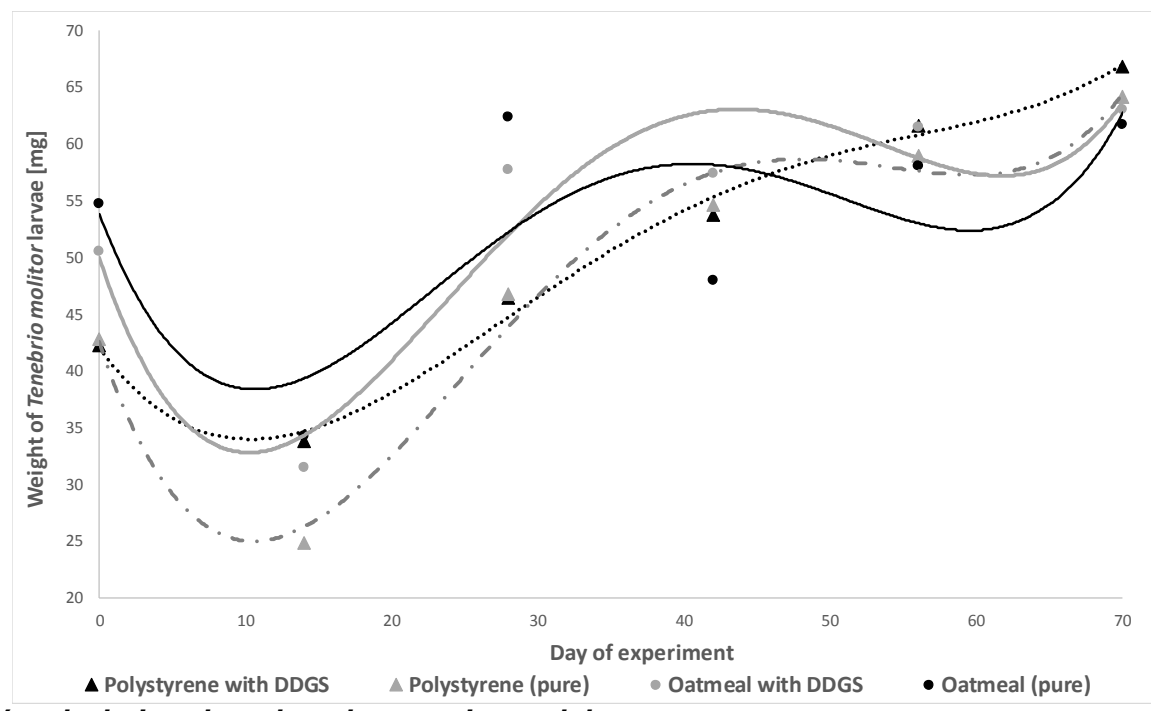

Source: author's calculations based on the experimental data

Fig. 1. Trend in changes of the weight of 1 mealworm larva during the experiment

While analysing the effect of an external source of nitrogen in the form of added DDGS, it was noticed that the additive had a positive influence on the weight of a single insect regardless of the diet. Loss of the weight of larvae fed Styrofoam with added DDGS was smaller and characterised by smaller fluctuations than among the larvae given pure Styrofoam without DDGS (Figure 1).

After 10 weeks, the mass of each tested substrate was found to have decreased (Table 2), suggesting that it had been ingested by the insects. The biggest decrease was noted in the control variant, with the substrate composed of oatmeal, which is a typical food for mealworms $(31.7 \%$ pure oatmeal, $32.7 \%$-oatmeal with added DDGS). The mass of Styrofoam given to larvae as food also decreased, albeit to a lesser extent, i.e. by 12-13 \%. Of the two Styrofoam substrates tested, a greater decrease in the weight was observed for the substrate enriched with DDGS. On the termination of the experiment, the mass decrease was as high as $13.2 \%$. Yang et al. (2018) maintain that an addition of nitrogen can even double the amount of degraded Styrofoam. Under more suiTable culture conditions (lower temperature and higher humidity), the initial mass of Styrofoam can decrease by as much as $31 \%$ (Yang et al., 2015). 


\section{Mass of a nutrient substrate [in g] at the beginning and end of the experiment}

\begin{tabular}{|c|c|c|c|c|}
\hline \multirow{2}{*}{ Day of experiment } & \multicolumn{2}{|c|}{ Polystyrene } & \multicolumn{2}{c|}{ Oatmeal } \\
\cline { 2 - 5 } & Pure & (+) DDGS & Pure & $(+)$ DDGS \\
\hline $\mathbf{1}$ & 5.00 & 5.00 & 20.00 & 20.00 \\
\hline $\mathbf{7 0}$ & 4.39 & 4.34 & 13.67 & 13.47 \\
\hline
\end{tabular}

Source: author's calculations based on the experimental data

The highest decrease in the mass of oatmeal was noticed after 14 days (the first measurements), where it reached $2.42 \mathrm{~g}$ for oatmeal with DDGS and $2.51 \mathrm{~g}$ for pure oatmeal. During the consecutive measurements, made at two-week intervals, the noted losses of the mass of nutrient substrates were similar, $1 \mathrm{~g}$ on average for both oatmeal with DDGS and pure oatmeal. Based on the plotted trend lines, a steady decrease in the mass of the substrate was identified in both combinations with oatmeal (with and without DDGS) (Figure 2).

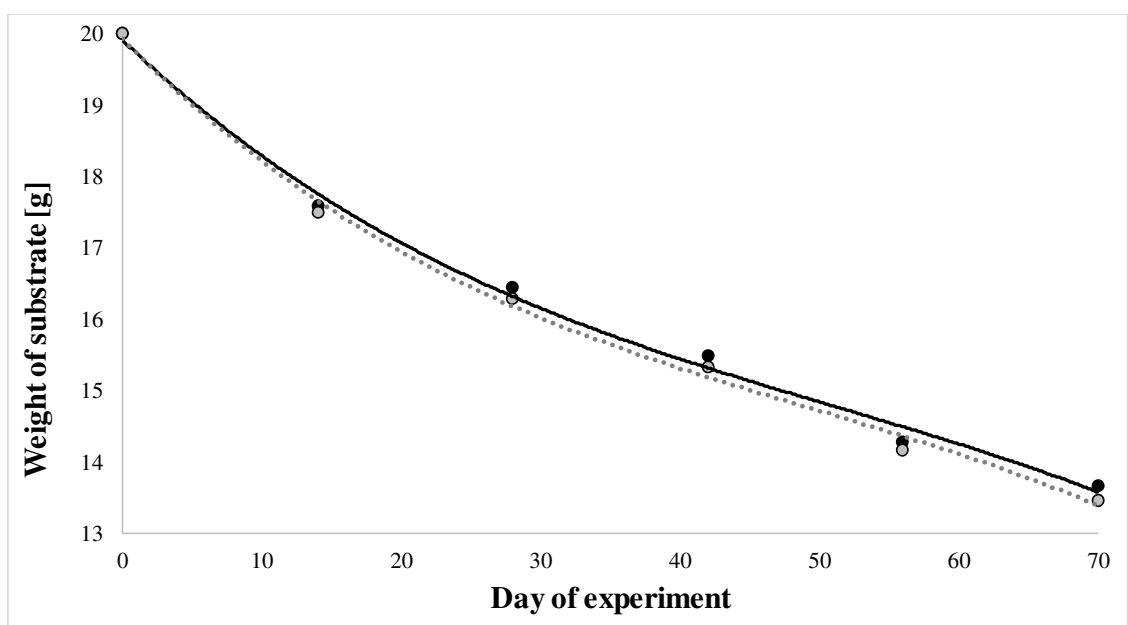

Source: author's calculations based on the experimental data

Fig. 2. Trend in the loss of weight of oatmeal substrates during the experiment (black points - with DDGS, grey - without DDGS)

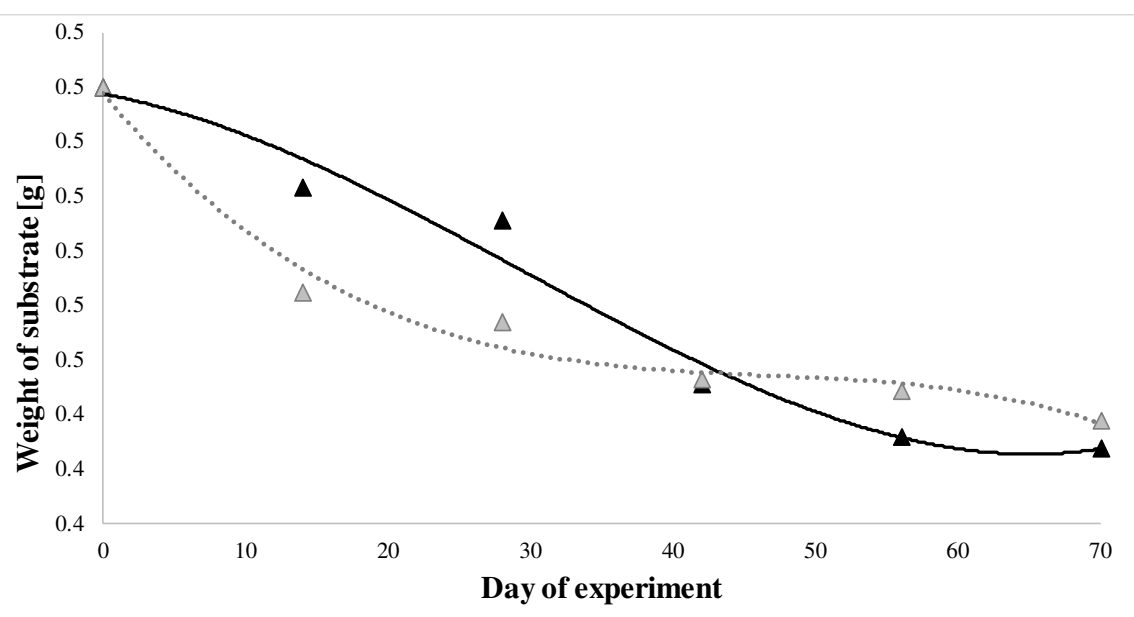

Source: author's calculations based on the experimental data

Fig. 3. Trend in the loss of weight of Styrofoam substrates during the experiment (black points - with DDGS, grey - without DDGS) 
Losses in the weight of Styrofoam as a substrate could also be observed during the experiment. On average, there was $9.3 \mathrm{mg}$ less of Styrofoam daily. The addition of DDGS effected a regular decrease in the weight of the substrate throughout the experiment, which in the other variant using the Styrofoam substrate lacking DDGS was inhibited after about 50 days (Figure 3).

\section{Biochemical analysis}

The level of enzymatic activity to a large extent depends on a diet (Howis, 2012). Regardless of the type of food supplied to the larvae, their enzymatic activity was confirmed, which implicates that microbiota of mealworm larvae could be employed for the sake of recycling synthetic material waste (Table 3). Enzymes are secreted by both larvae and their digestive tract microorganisms, and the combined activity of the released enzymes generates better effects as regards digestion of waste (Kosewska, 2018). Our analysis of the current results revealed that a higher enzymatic activity in the digestive tracts appeared in larvae fed Styrofoam than in the ones receiving oatmeal (Table 3). This may indicate the high adaptability of Tenebrio molitor and rapid multiplication of the gut microorganisms, which supported the digestion of the food that is not typical for mealworm. The results implicate the multitude of processes which are run in order to enable Styrofoam decomposition. The more processes there are, the better a given food is digested by larvae and their intestinal microorganisms. However, the absence of any disturbances in enzymatic processes and even their improved efficiency are suggestive of the digestive system's homeostasis being maintained in a situation when larvae are fed synthetic material. Our comparison of the diets showed a much lower enzymatic activity of the digestive tracts of larvae receiving oatmeal, which testifies to a lower biodiversity of their microbiota, as the source of food did not present any special requirements regarding its decomposition. The highest activity was noted in the tests of the activity of $\beta$ glucosidase and fermentation-oxidation of amygdalin. High activity was also demonstrated in the tests concerning the fermentation-oxidation of arabinose and reduction of nitrogen compounds. Their adequate amounts in the digestive system is ensured by microorganisms which multiply when the quantity of these compounds is limited (Engel and Moran, 2013). Then, the microorganisms conduct various processes in order to achieve an appropriate level of nitrogen compounds. An example is the microflora living in the digestive tract of termites, because it converts nitrogen metabolites of the insects into the forms that can be re-used (Honghoh et al., 2008). In turn, cockroaches comprise in their digestive tract certain bacteria that store nitrogen by converting it into uric acid (Sabree et al., 2009). Therefore, the enrichment of a substrate with a source of nitrogen, such as DDGS, resulted in the larvae and their gut microorganisms directing their activity elsewhere, not having to focus on acquiring nitrogen, and consequently the results of assays testing enzymatic activity were higher. On the other hand, it is worth noticing that an addition of DDGE activated proteolytic processes in both diets. Providing the larvae with a diet composed of Styrofoam intensified the reaction of fermentation-oxidation of most sugars, including glucose, mannitol and melibiose. Increased activity after an application of the Styrofoam diet was also noticed in the case of assimilation reactions, e.g. assimilation of adipic acid or malic acid. 


\section{Changes in the metabolism of microbiota inhabiting the digestive system of Tenebrio molitor depending on the nutrient substrate provided}

\begin{tabular}{|c|c|c|c|c|c|}
\hline \multirow[b]{2}{*}{ Process } & \multirow[b]{2}{*}{ Active ingredients } & \multicolumn{2}{|c|}{ Polystyrene } & \multicolumn{2}{|c|}{ Oatmeal } \\
\hline & & $\begin{array}{c}(+) \\
\text { DDGS }\end{array}$ & Pure & $\begin{array}{c}(+) \\
\text { DDGS }\end{array}$ & Pure \\
\hline NO3 reduction & potassium nitrate & 3 & 3 & 2.5 & 3 \\
\hline indole production & L-tryptophane & 2 & 2 & 2 & 2 \\
\hline acetoin production & sodium pyruvate & 2 & 2 & 2.5 & 2.5 \\
\hline protease & gelatin (bovine origin) & 0.5 & 0 & 2 & 0 \\
\hline B-glucosidase & esculin ferric citrate & 3 & 3 & 3 & 3 \\
\hline ß-galactosidase & 4-nitrophenyl-ßD-galactopyranoside & 3 & 3 & 2 & 2 \\
\hline arginine dihydrolase & L-arginine & 3 & 3 & 1.5 & 2.5 \\
\hline ornithine decarboxylase & L-ornithine & 3 & 3 & 3 & 1 \\
\hline \multirow{8}{*}{ 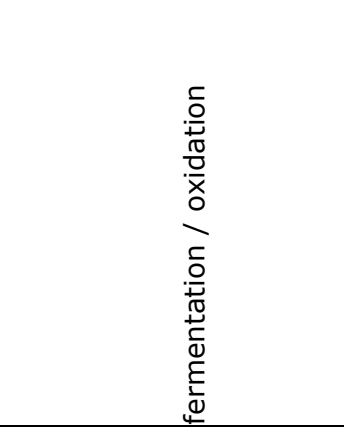 } & D-mannitol & 3 & 3 & 2.5 & 1 \\
\hline & inositol & 0.5 & 0 & 0 & 0 \\
\hline & D-sorbitol & 2 & 2 & 1 & 1 \\
\hline & L-rhamnose & 2 & 3 & 1.5 & 1 \\
\hline & D-sucrose & 1 & 2 & 1.5 & 1.5 \\
\hline & D-melibiose & 2 & 0.5 & 0.5 & 0 \\
\hline & amygdalin & 3 & 3 & 3 & 3 \\
\hline & L-arabinose & 3 & 3 & 2.5 & 3 \\
\hline \multirow{8}{*}{ 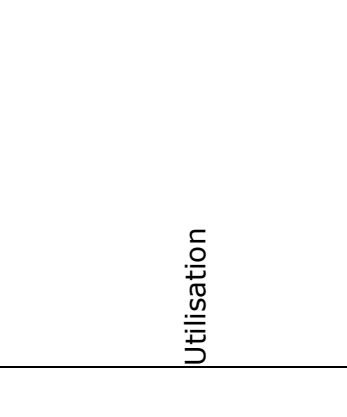 } & D-glucose & 3 & 3 & 2.5 & 3 \\
\hline & D-mannose & 2 & 1.5 & 2 & 1.5 \\
\hline & $\mathrm{N}$-acetyl-glucosamine & 2 & 2 & 1.5 & 2 \\
\hline & D-maltose & 2.5 & 2.5 & 2 & 2 \\
\hline & potassium gluconate & 2.5 & 2.5 & 2 & 1.5 \\
\hline & adipic acid & 0 & 0.5 & 0 & 0 \\
\hline & malic acid & 2.5 & 2.5 & 0.5 & 1 \\
\hline & & 50.5 & 50 & 41.5 & 37.5 \\
\hline
\end{tabular}

Source: author's calculations based on the experimental data

\section{Implementation of research results}

Reviewing the current methods of the recycling of Styrofoam, and particularly incineration, which puts a heavy burden on the environment, the use of mealworm larvae to decompose this synthetic material seems promising. This can be achieved by creating special rooms and containers, for the purpose of this method called insectoboxes, where Styrofoam waste will be decomposed. To ensure smooth processing, it is necessary to maintain relatively constant conditions inside an insectobox, such as the temperature of 20-25 and humidity at 60-80 \%. Such conditions can be achieved when the culture is conducted in a room in which the temperature can be controlled. Appropriate humidity can be maintained by regular spraying of the insects with water or by adding some biomass waste to the substrate. Our experiment demonstrated that mealworm larvae were able to degrade $13.2 \%$ of Styrofoam, i.e. $0.66 \mathrm{~g}$, in 10 weeks. It can therefore be assumed that if the density of larvae was 8 times higher (from 100 to 800 larvae) and the same conditions were maintained as during our experiment, then 10 weeks would be enough to degrade $100 \%$ of the initial mass of Styrofoam ( 5 g). Assuming that 800 larvae utilise $5 \mathrm{~g}$ of Styrofoam in 10 weeks, then 160000 larvae would be needed to degrade $1 \mathrm{~kg}$ of Styrofoam waste. This number of larvae, providing that a single larva on a Styrofoam diet with DDGS weighs $0.05 \mathrm{~g}$ on average, would reach a total weight of $8 \mathrm{~kg}$. Thus, 
larvae should be placed in appropriately large boxes. However, this is not a minimal capacity, and should a larger-scale process be needed, larvae could be kept in boxes of a smaller convertible capacity per specimen. It is therefore possible to use a container with the capacity of $800 \mathrm{dm} 3$, assuming that $0.5 \mathrm{dm} 3$ capacity falls for 100 larvae. When implementing this technology, it is advisable to remember to use insects that have previously had Styrofoam added to their diet, because this will considerably improve the process of digestion of this waste and reduce the mortality rate among larvae.

\section{Conclusions}

1) Mealworm larvae are able to digest Styrofoam.

2) Addition of an external source of nitrogen in the form of DDGS has a positive effect on the weight of an individual larva foraging on such untypical food as polystyrene, by improving the conditions for the population of insects and increasing the chances of successful utilisation of this waste.

3) The digestive system of a mealworm including the microbiota inhabiting it presents a higher enyzmatic activity when fed polystyrene, especially mixed with an external source of nitrogen, such as DDGS, than on a diet typical for this species. Styrofoam with added DDGS is a waste which can be recycled with the help of mealworm larvae.

4) When adequate conditions are ensured, it is possible to use mealworm larvae to recycle polystyrene waste, which might become an important element supporting the protection of our planet in compliance with the rules of sustainable development.

5) The biochemical assays type $A P I \circledast$ are a very good biomarker of the condition of larvae fed hazardous waste.

\section{Bibliography}

1. Juda-Rezler, K., Manczarski, p. (2010). Zagrozenia zwiazane z zanieczyszczeniem powietrza atmosferycznego i gospodarka odpadami komunalnymi. Nauka, No 4. pp. 97-106.

2. Thompson, R.C., Swan, S.H., Moore, C.J., Vom Saal, F.S. (2009). Our plastic age. Royal Society. 364 (1526), pp. 1973-1976.

3. Jambeck, J.R., Geyer, R., Wilcox, C., Siegler, T.R., Perryman, M., Andrady, A., Narayan, R., Law, K.L. (2015). Marine pollution. Plastic waste inputs from land into the ocean. Science, No 347, pp. 768-771.

4. Baker, I. (2018). Fifty Materials That Make the World. Springer. Dartmouth College-Hanover USA, p. 271.

5. Zebek, E. (2018). Zasady gospodarki odpadami w ujeciu prawnym i srodowiskowym. Kortowski Przeglad Prawniczy Monografie(KPPMonografie). Olsztyn, p. 371.

6. Yang, J., Yang, Y., Wu, W.M., Zhao, J., Jiang, L. (2014). Evidence of Polyethylene Biodegradation by Bacterial Strains from the Guts of Plastic-Eating Waxworms. Environmental Science \& Technology 2014; 48(23), pp. 13776-13784.

7. Yang, J., Wu, W., Zhao, J., Yang, R. (2015). Biodegradation and Mineralization of Polystyrene by PlasticEating Mealworms: Part 1. Chemical and Physical Characterization and Isotopic Tests. Environmental Science \& Technology 2015; 49(20), pp. 12080-12086.

8. Bombelli, P., Howe, C.J., Bertocchini, F. (2017). Polyethylene bio-degradation by caterpillars of the wax moth Galleria mellonella. Current Biology 2017; 27(8), pp. 292-293.

9. Ritter, S.K. (2017). Wax worms take a liking to plastic shopping bags. Chemical \& Engineering News 2017; 95(18), pp. 10-11.

10. Pelley, J. (2014). Pantry Pests Harbor Plastic-Chomping Bacteria. Chemical \& Engineering News. https://cen.acs.org/articles/92/web/2014/12/Pantry-Pests-Harbor-Plastic-Chomping.html. Access: 20.02.2019.

11. Nawrot, J. (2001). Owady - szkodniki magazynowe. Themar Import-Eksport, Warszawa, p. 149.

12. Ramos-Elorduy, J., González, E.A., Hernández, A.R., Pino, J.M. (2002). Use of Tenebrio molitor (Coleoptera: Tenebrionidae) to Recycle Organic Wastes and as Feed for Broiler Chickens. Journal of Economic Entomology 2002; 95(1), pp. 214-220.

13. Weiner, A., Paprocka, I., Kwiatek, K. (2018). Wybrane gatunki owadow jako zrodlo skladnikow odzywczych w paszach. Zycie Weterynaryjne 2018; 93(7), pp. 499-504.

14.Siemianowska, E., Kosewska, A., Aljewicz, M., Skibiniewska, K., Polak-Jaszczuk, L., Jarocki, A., Jedras, M. (2013). Larvae od mealworm (Tenebrio molitor L.) as European novel food. Agricultural Sciences 2013; 4(6), pp. 287-291. 
15. Fialkowski, p. (2016). Robale w Robakowie pod Poznaniem - pierwsza w Polsce fabryka insektow. Magazyn Poznanski. http://poznan.wyborcza.pl/poznan/1,105531,19477818,robaki-w-robakowie-pod-poznaniempierwsza-w-polsce-fabryka.html. Access: 20.02.2019.

16. Drahl, C. (2015). Plastics recycling with microbes and worms is further away than people think. https://cen.acs.org/environment/sustainability/Plastics-recycling-microbes-worms-further/96/i25. Access: 4.12.2018.

17. Yang, S.S., Brandon, A.M., Xing, D.F., Yang, J., Pang, J.W., Criddle, C.S., Ren, N.Q., Wu, W.M. (2018). Progresses in Polystyrene Biodegradation and Prospects for Solutions to Plastic Waste Pollution. IOP Conference Series: Earth and Environmental Science. Vol. 150, pp. 1-10.

18. Howis, M. (2012). Aspekty biologiczne rodziny pszczelej- relacje miedzy Apis mellifera a Varroa destructor przy stosowaniu zabiegow ograniczajacych populacje pasozyta. Uniwersytet Przyrodniczy we Wrocławiu. Praca doktorska.Wydział Biologii i Hodowli Zwierzat. Wrocław, p. 109.

19. Kosewska, O. (2018). Porownanie parametrow enzymatycznych w przewodzie pokarmowym macznika mlynarka (Tenebrio molitor L.) w zaleznosci od podawanego pokarmu. Monografia. Red. Tanska, M., Sosna, p. Koła Naukowe szkola tworczego dzialania - Nauki Rolnicze i Weterynaryjne. Wyd. ABADA, Olsztyn. Volume 5 (2), pp 5-16.

20. Engel P., Moran, N.A. (2013). The gut microbiota of insects - diversity in structure and function. FEMS Microbiology Reviews 2013; 37(5), pp. 699-735.

21. Hongoh, Y., Sharma, V.K., Prakash, T., Noda, S., Taylor, T.D., Kudo, T., Sakaki, Y., Toyoda, A., Hattori, M., Ohkuma, M. (2008). Complete genome of the uncultured Termite Group 1 bacteria in a single host protist cell. Proceedings of the National Academy of Sciences of the USA 2008; 105, pp. 5555-5560.

22. Sabree, Z.L., Kambhampati, S., Moran, N.A. (2009). Nitrogen recycling and nutritional provisioning by Blattabacterium, the cockroach endosymbiont. Proceedings of the National Academy of Sciences of the USA 2009; 106(46), pp. 19521-19526. 